\title{
O AGIR LINGUAGEIRO E A PRÁTICA DE PRODUÇÃO TEXTUAL NA ESCOLA
}

\author{
Eliana Merlin Deganutti de Barros* \\ Universidade Estadual do Norte do Paraná (UENP) \\ Cornélio Procópio, Paraná, Brasil
}

\begin{abstract}
Resumo: Neste artigo, tendo como objeto de análise o processo de escrita de uma carta de reclamação ancorado na metodologia das sequências didáticas, apresentamos um panorama teórico do agir comunicativo, a fim de se chegar a um quadro conceitual da ação linguageira usado por nossa pesquisa de doutoramento (abordagem qualitativointerpretativa, de cunho etnográfico-intervencionista) como parâmetro para a análise da produção textual em situação de ensino-aprendizagem da língua. Esse quadro é resultado de empréstimos de conceitos da Teoria da Atividade de Leontiev e da sua apropriação pelos pesquisadores do Interacionismo Sociodiscursivo. A conscientização do processo que envolve a ação linguageira mostrou-se de suma importância no clareamento de aspectos envolvidos no processo do ensino da produção de textos em ambiente escolar.
\end{abstract}

Palavras-chave: Teoria da atividade. Ação linguageira. Produção de textos.

1 INTRODUÇÃO

Todas as espécies animais têm formas de agir socializadas, porém é no agir verbalizado que o ser humano distingue-se dos demais animais, uma vez que a espécie humana é a única, aparentemente, a ter desenvolvido a linguagem verbal e a mobilizar signos organizados em artefatos semióticos repletos de sentido, isto é, em textos/discursos. Isso permitiu ao homem "construir um espaço gnoseológico, ou seja, mundos de conhecimentos que podem se tornar autônomos em relação às circunstâncias individuais da vida, que podem se acumular no curso da história dos grupos" (BRONCKART, 2006, p. 137). Esse agir possibilitou ao homem, também, construir ferramentas (materiais e simbólicas) para intervir no mundo, transformando-o, bem como construir e acumular conhecimentos.

Mas qual a configuração desse agir linguageiro nos processos interacionais? E como ele se realiza no espaço escolar, no âmbito do ensino da escrita? Para tratar desses questionamentos, trazemos, neste artigo, um recorte de uma pesquisa de doutoramento ${ }^{1}$, a qual teve como objetivo investigar, no contexto brasileiro de ensino público da Língua Portuguesa, o funcionamento da metodologia que embasa o procedimento "sequência didática de gêneros", criado pelos pesquisadores do Interacionismo Sociodiscursivo (doravante ISD) para direcionar o ensino da produção de textos.

\footnotetext{
*Doutora em Estudos da Linguagem. Professora Adjunta. Email: edeganutti@hotmail.com.

${ }^{1}$ Pesquisa desenvolvida no Programa de Estudos da Linguagem da UEL, sob orientação da Profa. Dra. Elvira Lopes Nascimento.
} 
Para o ISD, a produção de um texto no locus escolar não pode ser uma simples tarefa de apropriação do código linguístico e das normas que regem a ortografia e a gramática da língua oficial. Ela deve ser fruto de uma ação linguageira na qual o aluno assume seu papel de agente e age intencionalmente para atingir os objetivos propostos (mesmo que simulados didaticamente), usando os instrumentos semióticos disponíveis na sua língua, ou seja, os diversos gêneros de textos que fazem parte da cultura letrada, legados a nós por gerações anteriores. Para isso, o papel da escola é fundamental, uma vez que é ela a principal agência de letramento (KLEIMAN, 2006). É, sobretudo, no ambiente escolar que o aluno desenvolve capacidades de linguagem (SCHNEUWLY; DOLZ, 2004) para agir verbalmente nas diversas práticas discursivas criadas pela sociedade e sedimentadas nas diversas esferas da comunicação (BAKHTIN, 2003) - do cotidiano, do trabalho, jornalística escolar, etc.

Reconhecendo a necessidade de a escola, sobretudo, a disciplina destinada ao ensino da língua materna, desenvolver capacidades de linguagem para que o jovem possa assumir seu papel de agente nas práticas sociais, é que o ISD propõe o procedimento sequência didática (doravante $\mathrm{SD}$ ), uma ferramenta para o ensino da produção textual, estruturada a partir dos conceitos pedagógicos que envolvem a noção de zona de desenvolvimento proximal $(Z D P)^{2}$ de Vigotski (2008). A SD é "uma seqüência de módulos de ensino, organizados conjuntamente para melhorar uma determinada prática de linguagem", cujo objetivo é buscar "confrontar os alunos com práticas de linguagem historicamente construídas, os gêneros textuais, para lhes dar a possibilidade de reconstruí-las e delas se apropriarem"3 (DOLZ; SCHNEUWLY, 2004, p. 51). Ela é um dispositivo que permite que os objetos de ensino da língua relacionados aos eixos da escrita, leitura, oralidade e análise linguística - sejam organizados em um projeto didático, a partir de um objeto unificador (NASCIMENTO, 2011): o gênero textual.

Tomando como aporte esse embasamento teórico-metodológico, a pesquisa de campo que subsidiou a investigação buscou a colaboração de uma professora da escola pública para realizar um projeto de produção escrita estruturado na metodologia das SD. Tal projeto foi desenvolvido em 2009, num $6^{\circ}$ ano do Ensino Fundamental ${ }^{4}$, tendo como objeto unificador o gênero "carta de reclamação" - texto epistolar não comercial, de ordem privada (não publicado pela imprensa), cujo objetivo é reclamar de problemas da comunidade.

Tomando como pano de fundo análises de processos envolvidos no projeto da produção escrita da carta de reclamação desenvolvido durante a pesquisa etnográfica de sala de aula ${ }^{5}$ (BORTONI-RICARDO, 2008), trazemos, neste artigo, uma discussão

\footnotetext{
${ }^{2}$ Barros (2013) traz um paralelo entre a metodologia das sequências didáticas e a noção de ZDP de Vigotski.

${ }^{3}$ A SD é composta por quatro etapas centrais: a apresentação da situação, a primeira produção, os módulos/oficinas e a produção final (cf. SCHNEUWLY; DOLZ, 2004).

${ }^{4}$ Contexto geral da pesquisa de campo: Escola Estadual pública, da periferia da região Norte de Londrina (PR); $6^{\circ}$ ano, turma $\mathrm{A}$, do período matutino, com 33 alunos, a maioria em idade regular para a série, mas com sérios problemas de letramento.

${ }^{5}$ A pesquisa de doutoramento enquadra-se na área da Linguística Aplicada, a partir de uma abordagem qualitativo-interpretativa, de cunho etnográfico-intervencionista.
} 
sobre o conceito epistemológico do agir - geral e linguageiro -, tendo como foco a Teoria da Atividade de Leontiev $(1983,2006)$ e a adaptação dessa Teoria pelos pesquisadores do ISD. Nesse diálogo epistemológico, elaboramos um esquema da ação linguageira, utilizando conceitos originais da Teoria Atividade de Leontiev e a sua apropriação pelos pesquisadores do ISD. Para complementar a discussão teórica, trazemos, também, fundamentos para a análise do contexto de produção do agir pela linguagem. Como resultados empíricos, apresentamos análises: do primeiro módulo da SD construída, cujo objetivo é motivar o aluno para o ato da reclamação, focando o ponto de vista do agir comunicativo; das produções de um aluno (produção inicial e final), selecionadas como exemplo de um agir linguageiro "autêntico", mesmo que em situação de ensino-aprendizagem.

\section{AGIR LINGUAGEIRO NO QUADRO GERAL DA ATIVIDADE}

A fim de esquematizar um quadro teórico da atividade linguageira que possa ser usado na análise dos processos que envolvem a produção textual, trazemos, primeiramente, as contribuições da Teoria da Atividade de Leontiev (1983, 2006), inspirada no materialismo dialético de Marx ${ }^{6}$. Nessa discussão, apresentamos, também, a adaptação do ISD para a abordagem da atividade e um esquema da ação linguageira que aborda tanto conceitos de Leontiev quanto do ISD. É a partir desse esquema que nós, posteriormente, analisamos, na seção analítica, o primeiro módulo da SD da carta de reclamação, elaborada para a intervenção em sala de aula. Para ilustrar as discussões que se seguem, procuramos, sempre que possível, trazer como exemplo o objeto de ensino unificador da SD - o gênero "carta de reclamação".

Para iniciar, apresentamos as proposições de Leontiev (2006), pois foi esse autor soviético quem sistematizou, a partir dos estudos de Marx, o conceito de atividade. Para o autor, atividade refere-se aos "processos psicologicamente caracterizados por aquilo a que o processo, como um todo, se dirige (seu objeto), coincidindo sempre com o objetivo que estimula o sujeito a executar esta atividade, isto é, o motivo" (2006, p.68). Nessa teoria, a motivação para o agir deveria partir do próprio objeto para que, então, o processo se configurasse em uma atividade. Para exemplificar essa ideia, o autor apresenta a seguinte situação: um estudante começa a ler um livro como preparação para uma prova, porém é avisado de que tal leitura não é mais essencial para o exame. Nesse caso, ele pode desistir prontamente da leitura ou continuá-la, independentemente da nova situação. No primeiro caso, nota-se que não foi o conteúdo do livro (objeto) que motivou o processo, mas a necessidade de ser aprovado no exame, diferentemente do segundo caso, no qual a motivação partiu do próprio objeto - o conteúdo do livro. Para Leontiev (2006), no primeiro caso, a atividade não é a leitura em si, mas a preparação para a prova. Vemos que, para o autor, uma das principais características da atividade é seu caráter objetival.

\footnotetext{
${ }^{6}$ Embora o autor aborde o agir geral, é perfeitamente cabível fazer uma transposição dos conceitos trabalhados para o âmbito do agir linguageiro.
} 
Formulando seu quadro conceitual, o autor soviético diferencia atividade de ação. Esta última seria caracterizada por um "processo cujo motivo não coincide com seu objetivo (isto é, com aquilo para o qual ele se dirige)" (p. 69). No caso do exemplo dado, a leitura dirigida para a preparação do exame seria, na verdade, uma ação, pois aquilo para o qual ela se dirige - o conteúdo do livro - não é exatamente a sua motivação. A ação, vista dessa forma, tem um caráter "mecânico". Entretanto, "para que a ação surja e seja executada é necessário que seu objetivo apareça para o sujeito, em sua relação com o motivo da atividade da qual ele faz parte" (LEONTIEV, 2006 p. 69). Ou seja, o objetivo da ação de ler para passar no exame tem de estar em articulação direta com a atividade principal de ler para dominar o conteúdo do livro.

Para ilustrar, fazemos um paralelo com um dos focos da pesquisa - a apropriação de um gênero de texto, a carta de reclamação. Na concepção de Leontiev (2006), o aluno, ao agir pela linguagem por meio da escrita da carta de reclamação, estaria inserido em uma atividade linguageira quando a motivação do seu agir coincidisse com os objetivos do gênero - reclamar formalmente para as autoridades competentes, no papel discursivo de um cidadão, sobre problemas da comunidade, a fim de solucionálos. Poderíamos considerar uma ação de linguagem quando a motivação, por exemplo, se vinculasse a fatores pedagógicos como, por exemplo, tirar uma boa nota, passar de ano, ou simplesmente cumprir uma tarefa escolar. No último caso, vemos que o objetivo da ação de escrever a carta para cumprir uma obrigação escolar está diretamente relacionado ao objetivo da atividade linguageira, uma vez que, sem o conhecimento de tal objetivo - reclamar de um problema da comunidade - a ação não se realizaria.

Partindo desse ponto de vista, Leontiev (2006) distingue dois conceitos no seu quadro teórico da atividade: os motivos compreensíveis (motivação da atividade principal, do conhecimento do sujeito do agir), e os motivos eficazes (aqueles que efetivamente movem a ação). Fazendo um paralelo com outros dois conceitos da Teoria da Atividade de Leontiev (1983) - significação e sentido -, podemos dizer que a significação da atividade estaria para os motivos compreensíveis, assim como o sentido estaria para os motivos eficazes. Para o autor, significação e sentido são, muitas vezes, não coincidentes e até contraditórios, sendo essa não coincidência denominada alienação ${ }^{7}$. Por exemplo, o significado social (ou motivação compreensível) do trabalho do operário é produzir com eficiência algum produto, embora o sentido (motivação eficaz) possa ser o de ganhar um bom salário para sobreviver.

No exemplo do agir linguageiro exposto, também há essa alienação motivacional quando o sentido da escrita da carta passa a girar em torno apenas do cumprimento da tarefa escolar e o significado social do gênero torna-se simplesmente um pretexto para a escrita textual. Esse processo, porém, não é estável: os motivos compreensíveis podem se transformar em motivos realmente eficazes, e se inserir em uma "atividade autorregulada", ou seja, significação e sentido se tornariam a mesma coisa, fora de um contexto de alienação motivacional. No nosso exemplo, o aluno pode se transformar em um agente-produtor autônomo, desvinculado das obrigações escolares, e agir, por meio da linguagem, numa situação social específica, na produção autêntica de uma carta de

\footnotetext{
${ }^{7}$ Conceito adaptado do materialismo dialético de Marx.
} 
reclamação, motivado pela significação social do gênero. Tudo vai depender, segundo Leontiev (2006), de uma tomada plena de consciência da esfera de relações envolvida nessa atividade. No âmbito do ensino, essas relações são, na maioria das vezes, novas para o aluno, por isso necessitam de um trabalho explícito e sistematizado para a "tomada de consciência". No caso da atividade de escrita da carta de reclamação, a esfera social é perpassada pelas relações hierárquicas entre a instituição "cidadão" e a instituição do "poder público" que rege a sociedade - relações essas que não fazem parte das atividades (gerais ou linguageiras) do cotidiano do aluno.

Para a análise dos dados gerados pela pesquisa, embora aderindo aos princípios gerais da Teoria da Atividade de Leontiev (2006), principalmente no que diz respeito ao caráter social e objetival da atividade, fazemos uma distinção entre atividade e ação, diferentemente da proposta do autor soviético, uma vez que tomamos por base as adaptações feitas pelo ISD - fonte teórica básica da nossa pesquisa - a esse aparelho conceitual. Mantemos, para tanto, a utilização dos conceitos de significação e sentido, assim como de motivação compreensível e eficaz, conforme postulados por Leontiev

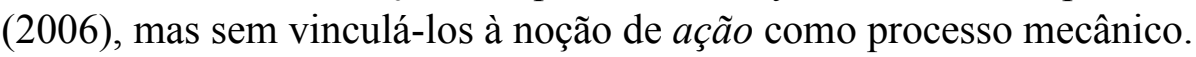

No quadro teórico do ISD, de forma geral, atividade é o termo utilizado para "designar uma leitura do agir que implica as dimensões motivacionais e intencionais mobilizadas por um coletivo organizado" (MACHADO, 2005, p. 249); "um formato social que organiza e regula as interações dos indivíduos com o meio" (BRONCKART, 2008, p. 123). As atividades, por sua vez, são constituídas de ações, a saber, "condutas que podem ser atribuídas a um agente particular, motivadas e orientadas por objetivos que implicam a representação e a antecipação de seus efeitos na atividade social" (MACHADO, 2005, p. 249). Isto é, a atividade estaria dirigida para o agir coletivo e, a ação, para o agir individual - acepção que mantemos na pesquisa.

$\mathrm{Na}$ perspectiva semiológica do agir proposta pelo ISD, de forma geral, para ser considerado ação, um evento precisa estar fundamentado no tripé: motivo, intenção e capacidade (física, psíquica ou linguageira). Assim, "o motivo, a intenção e a capacidade definem a responsabilidade desse ser humano no encadeamento dos fenômenos" (BRONCKART, 2006, p. 210). Por exemplo, a queda de um fruto de uma árvore é considerada apenas um acontecimento natural, diferentemente da ação de colher esse mesmo fruto. Na ilustração, a motivação poderia ser o fato de o sujeito estar com fome; a intenção poderia ser "comer o fruto"; já as capacidades seriam os recursos - físicos e cognitivos - para fazer tal ação.

Da mesma forma que o agir geral, uma ação linguageira configura-se como um evento (nesse caso, linguístico) movido por um motivo (ou razão para o agir), fruto de uma intenção (representação de um efeito) e imputável a um agente (sujeito que assume uma responsabilidade, por ser dotado de capacidades de linguagem).

$\mathrm{Na}$ concepção epistemológica e metodológica do agir linguageiro defendida pelo ISD, os gêneros de texto agem como instrumentos (recursos semióticos, externos ao sujeito) que possibilitam a mediação do homem com a situação/objeto de intervenção. Para o seu agir, o agente-produtor precisa mobilizar capacidades de linguagem (DOLZ; SCHNEUWLY, 2004), a saber, aptidões necessárias para o ato da produção linguageira. Segundo Dolz e Schneuwly (2004), as capacidades de linguagem podem ser subdivididas em três níveis: 


\section{Quadro 1 - Capacidades de linguagem}

\begin{tabular}{|l|l|l|}
\hline \multicolumn{1}{|c|}{$\begin{array}{c}\text { Capacidades } \\
\text { de ação }\end{array}$} & \multicolumn{1}{|c|}{$\begin{array}{c}\text { Capacidades } \\
\text { discursivas }\end{array}$} & \multicolumn{1}{|c|}{\begin{tabular}{c}
\multicolumn{1}{c|}{ Capacidades } \\
linguístico-discursivas
\end{tabular}} \\
\hline $\begin{array}{l}\text { Essa capacidade possibilita ao } \\
\text { agente-produtor fazer } \\
\text { representações do contexto da sua } \\
\text { ação de linguagem, adaptando sua } \\
\text { produção aos parâmetros do } \\
\text { ambiente físico, social e subjetivo. } \\
\begin{array}{l}\text { Enfim, esse nível de capacidade é } \\
\text { aquele que articula o gênero às } \\
\text { representações contextuais } \\
\text { internalizadas pelo agente- } \\
\text { produtor. }\end{array}\end{array}$ & $\begin{array}{l}\text { Essa capacidade } \\
\text { possibilita ao agente- } \\
\text { produtor fazer escolhas } \\
\text { no nível discursivo. No } \\
\text { modelo de análise do }\end{array}$ & $\begin{array}{l}\text { ISD, são aquelas } \\
\text { relacionadas à } \\
\text { infraestrutura geral de } \\
\text { um texto - plano geral, } \\
\text { tipos de discurso e } \\
\text { planificação sequencial. } \\
\text { linguístico-discursivas implicadas na } \\
\text { produção textual. No modelo de análise } \\
\text { do ISD, elas são representadas pelos: } \\
\text { mecanismos de textualização (conexão, } \\
\text { coesão nominal e coesão verbal); e } \\
\text { mecanismos enunciativos } \\
\text { (gerenciamento de vozes e } \\
\text { modalizações). Também entram nesse } \\
\text { nível, a seleção lexical e a construção } \\
\text { sintática dos enunciados. }\end{array}$ \\
\hline
\end{tabular}

Embora classificadas em três níveis distintos, as capacidades de linguagem não operam de forma compartimentada ou linear. Uma capacidade não age sozinha, pois ela é dependente das demais. Essa proposta de subdivisão funciona muito mais no plano metodológico da pesquisa. É justamente da articulação entre os três níveis que resulta a ação linguageira e o "sucesso" da produção de um texto. Dessa forma, não há como avaliar a mobilização das capacidades fora da sua ação de linguagem: "o 'competencial' não pode ser dissociado da própria ação; é, ao contrário, uma de suas propriedades constitutivas" (BRONCKART, 2006, p. 200). Sem a ação, os recursos/capacidades nada podem produzir ou reproduzir.

Fazendo uma articulação com a proposta da Teoria da Atividade de Leontiev (2006), podemos acrescentar dois conceitos à configuração geral do agir do ISD: a necessidade (que orienta e regula a ação a um meio objetival) e as operações para a realização de uma ação. No percurso histórico da humanidade, os seres humanos elaboram/adaptam inúmeros objetos para atender às suas necessidades, criando, nesse sentido, não apenas novos objetos, mas também novas necessidades que geram novas formas de atividades. Ou seja, a ação parte sempre de uma necessidade criada pelo ser humano no seu processo de desenvolvimento histórico-cultural. No âmbito do agir linguageiro não é diferente.

Tomemos como exemplo o advento da internet. Ao inventar essa ferramenta digital, o homem cria também novas necessidades de interação - as conversas online (simulação da conversa face a face), as trocas digitais de mensagens, a pesquisa bibliográfica digital, etc. -, o que faz emergir novas formas de atividade linguageira os chats, as redes sociais, os e-mails, as plataformas digitais, etc. As atividades são, assim, direcionadas pelas necessidades criadas pelo homem na sua intervenção no mundo. Entretanto, a necessidade, por si só, não desencadeia uma ação, ela apenas direciona-a. Para que a ação ocorra é preciso que a necessidade transforme-se em motivação e articule-se a uma intencionalidade e a um recurso para o agir.

Por exemplo, a necessidade de emagrecer não implica, obrigatoriamente, a ação de fazer um regime. Para que a ação ocorra o sujeito precisa estar motivado (seja motivação compreensível ou eficaz: saúde, estética, etc.), ter a intenção de fazer o 
regime para, por exemplo, "perder $5 \mathrm{~kg}$ ", assim como ter recursos para realizá-lo. Agora, quais os procedimentos necessários para que a ação se realize? Como operacionalizá-la? Por exemplo, para fazer um regime pode-se primeiramente ir a um nutricionista, que, com certeza, irá pedir exames preliminares para checar a saúde, e depois recomendar uma dieta controlada; com base nessa dieta, é preciso fazer compras de alimentos específicos, adequar os horários das refeições, matricular-se em uma academia, etc. A esses procedimentos necessários para a realização da ação, Leontiev (2006) dá o nome de operações. Para o autor soviético, além do caráter motivacional e intencional da ação, ela também apresenta um caráter operacional. Sendo assim, ele define operações como as formas de execução de uma ação, os vários procedimentos que o sujeito realiza para alcançar os seus objetivos acionais.

Dessa forma, incluímos na configuração geral da ação linguageira, tanto a noção de necessidade como o conceito de operações, ambos explorados por Leontiev (2006) na sua Teoria da Atividade. $O$ esquema a seguir sintetiza a funcionalidade da ação linguageira, sob o ponto de vista assumido na pesquisa.

\section{Figura 1 - Configuração da ação linguageira}

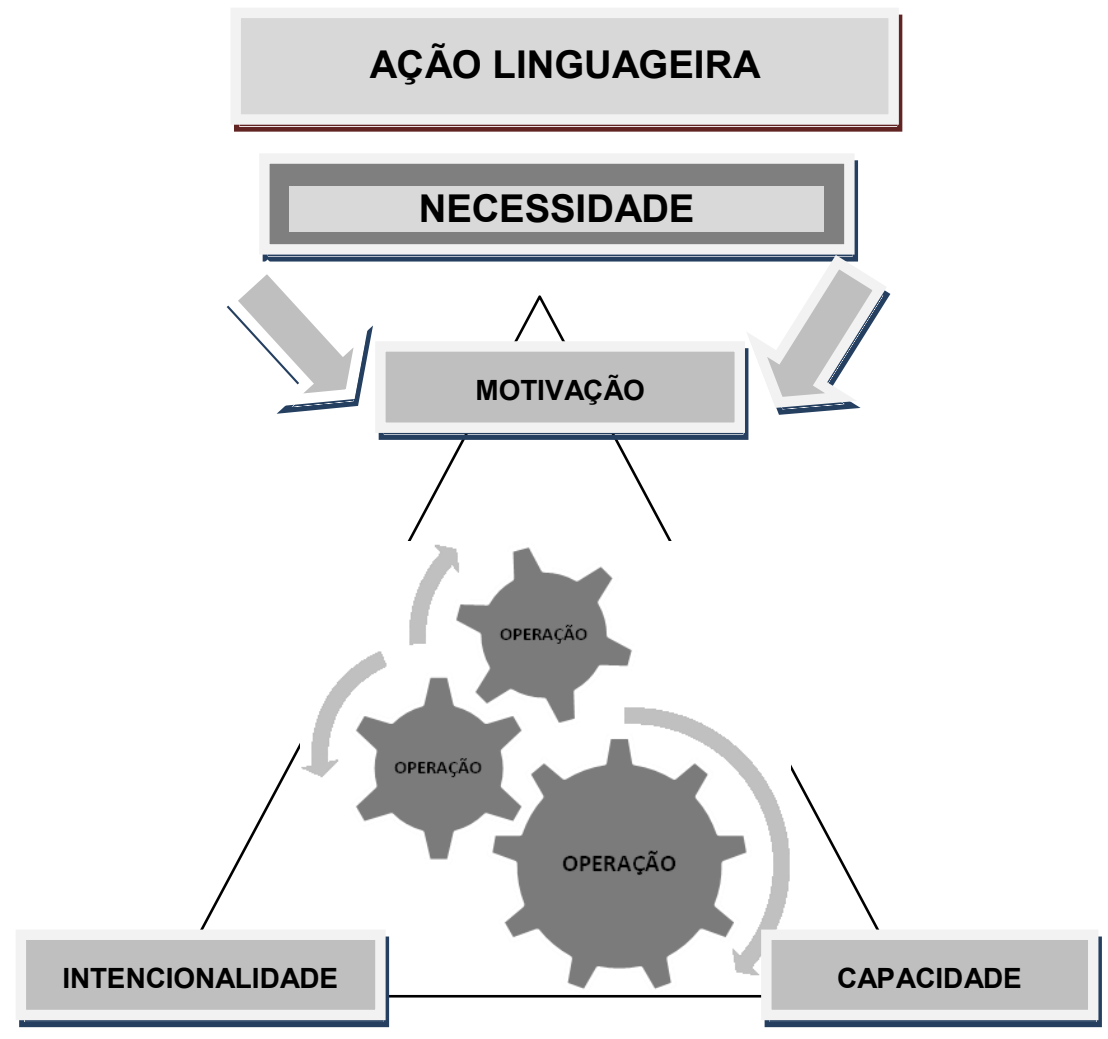

No exemplo da ação linguageira representada pela escrita da carta de reclamação, o esquema acional poderia ter a seguinte configuração: existe um problema na comunidade que necessita ser solucionado (por exemplo, ruas esburacadas) que, por si só, não desencadeia uma ação; assumindo o papel discursivo de cidadão, o sujeito, motivado a solucionar esse problema (motivo compreensível), idealiza um objeto semiótico (a carta de reclamação) que possa satisfazê-lo; intenciona, dessa maneira, 
reclamar e solicitar uma resolução para o problema, de maneira formalizada; para isso, deve ser dotado de capacidades de linguagem específicas que the possibilitem operacionalizar o agir, realizar as operações próprias desse objeto semiótico, como, por exemplo, saber textualizar sequencialmente o texto.

\section{O CONTEXTO DE PRODUÇÃO DA AÇÃO LINGUAGEIRA}

$\mathrm{Na}$ teoria do agir comunicativo de Habermas (1989, 1999) - uma das bases epistemológicas do ISD -, o processo de interação verbal se dá no que o autor denomina "mundo vivido", onde relações interpessoais se organizam e onde ocorrem as problematizações e discussões relativas à práxis humana. Esse "mundo vivido", segundo Siebeneichler (1989), seria composto por três dimensões: a) a cultura - esfera que retém os saberes da humanidade; b) a sociedade - esfera responsável pela instituição de normas e regras, onde os indivíduos legitimam suas próprias convicções (a noção de convivência advém dessa esfera); c) a personalidade - síntese da cultura e da sociedade em que o indivíduo se insere, possibilitada pelo agir pela linguagem. Para Habermas (1999), o agir comunicativo acontece, portanto, nos eixos cultural, social e subjetivo, nos quais os sujeitos buscam reconhecer-se na sua individualidade e, ao mesmo tempo, como um ser coletivo que se comunica e interage com seus pares.

No quadro conceitual do ISD, a ação linguageira é a produção de um agente que constrói, conjuntamente, as coordenadas formais de três mundos formais: mundo objetivo, social e subjetivo. Essas coordenadas, "tornando possível a avaliação das interações em curso, fazem estas últimas passarem do estatuto de acontecimento natural ao estatuto de atividade unificadora de ações significantes" (BRONCKART, 2006, p.74). A representação desses mundos passa a constituir, pois, o contexto específico de suas ações.

Para Bronckart (2003), a expressão situação de ação de linguagem (e suas similares: condições de produção, contexto de produção, situacionalidade, etc.) refere-se às propriedades dos mundos formais que exercem influência sobre a produção de um texto. O autor ressalta que é preciso distinguir, no entanto, a situação da ação linguagem externa e interna. A primeira diz respeito às "características dos mundos formais, tais como uma comunidade de observadores poderia descrever" (p. 91). Já a segunda, refere-se às "representações sociais sobre esses mesmos mundos, tais como um agente as interiorizou" (p. 91). E é justamente a situação de ação interiorizada que irá influenciar efetivamente a produção de um texto.

Entretanto, como um pesquisador/leitor/ouvinte pode ter acesso a essa situação, já que é ela que condiciona a ação de linguagem? $\mathrm{Na}$ verdade, não temos como ter acesso à "verdade" das representações contextuais internas de um agente-produtor. De acordo com Bronckart (2003, p. 92), "metodologicamente, a partir das informações referentes à situação de ação externa, não podemos formular senão hipóteses sobre a situação efetiva do agente". No quadro teórico-metodológico elaborado por Bronckart (2003), essas representações configuram-se na base de orientação do agir linguageiro, a partir da qual as decisões de ordem discursiva e linguística são efetivadas.

De acordo com o modelo bronckartiano, para produzir um texto o agente precisa mobilizar suas representações sobre os três mundos formais, tomando duas direções: 
a) as representações são requeridas como contexto da produção textual, exercendo influência pragmática sobre a organização geral do texto;

b) as representações são requeridas como conteúdo temático ou referente e vão influenciar os aspectos pragmáticos da organização textual.

Para o ISD, os fatores contextuais que exercem influência (necessária, mas não mecânica) sobre as produções linguageiras podem ser agrupados, levando-se em consideração a proposição dos mundos formais de Habermas (1999), em dois conjuntos: a) o mundo físico da ação de linguagem; b) o mundo sociossubjetivo da ação de linguagem. No plano físico, o texto "resulta de um comportamento verbal concreto, desenvolvido por um agente situado nas coordenadas do espaço e do tempo" (BRONCKART, 2003, p. 93). No plano sociossubjetivo, a produção textual inscreve-se "no quadro de uma forma de interação comunicativa que implica o mundo social (normas, valores, regras, etc.) e o mundo subjetivo (imagem que o agente dá de si ao agir)" (BRONCKART, 2003, p. 93). O quadro a seguir mostra as categorias abordadas pelo ISD para o tratamento desses dois planos contextuais:

\section{Quadro 2 - Os parâmetros do contexto de produção}

\begin{tabular}{|l|l|}
\hline $\begin{array}{l}\text { Contexto físico: coordenadas espaço- } \\
\text { temporais em que se dá a ação de } \\
\text { linguagem implicadas na produção de um } \\
\text { texto }\end{array}$ & $\begin{array}{l}\text { Contexto sociossubjetivo: normas, valores, regras sociais, } \\
\text { etc., assim como a imagem que o agente faz de si e do } \\
\text { destinatário ao agir - implicados no quadro de uma forma } \\
\text { de interação comunicativa }\end{array}$ \\
\hline $\begin{array}{l}\text { - O lugar físico de produção } \\
\text { - O momento de produção }\end{array}$ & $\begin{array}{l}\text { O lugar social no qual o texto é produzido (escola, } \\
\text { mídia, família, etc.) }\end{array}$ \\
\hline $\begin{array}{l}\text { O emissor: pessoa que produz } \\
\text { fisicamente o texto }\end{array}$ & $\bullet$ A posição social do emissor: ou enunciador \\
\hline $\begin{array}{l}\text { O receptor: a(s) pessoa(s) que } \\
\text { recebe(m) concretamente o texto }\end{array}$ & • A posição social do receptor: ou destinatário \\
\hline
\end{tabular}

Fonte: adaptado de Bronckart (2003)

No modelo do ISD, o estatuto do sujeito que produz e recebe fisicamente um texto deve ser diferenciado do seu estatuto psicossocial, isto é, dos papéis discursivos que o sujeito assume na ação linguageira. Um indivíduo - entidade física - pode, dessa forma, assumir inúmeros papéis discursivos, dependendo da situacionalidade da ação linguageira. Por exemplo, uma jovem senhora pode agir por meio da linguagem como mãe, esposa, filha, aluna, professora, etc. Esses papéis não são determinados, a priori, pelo gênero, mas pelas representações do sujeito sobre o contexto da ação. Pode-se, assim, representar um papel de "mãe" ou "conselheira", mesmo acionando o gênero "aula", que, a princípio, demandaria um sujeito na função de "professora". Para denominar, então, esse emissor-enunciador, o ISD usa a terminologia agente-produtor.

Na perspectiva teórica em questão, a ação de linguagem pode ser descrita sem que se faça menção às características linguísticas do texto que vai concretizá-la. No caso da ação da escrita de uma carta de reclamação, podemos descrevê-la da seguinte forma (hipoteticamente): no dia Y, em sua casa (espaço-tempo da produção), um sujeito $\mathrm{X}$ (emissor), assumindo o papel discursivo de cidadão (enunciador), motivado pela 
necessidade de solucionar um problema da sua comunidade (conteúdo temático/referente), e com a intenção de reclamar formalmente para a autoridade competente (receptor/destinatário) para tentar solucionar tal problema (objetivo), escreve uma carta de reclamação (objeto textual) - com base em suas capacidades linguageiras de operacionalizar o agir.

No caso da nossa intervenção didática, o aluno (emissor) precisou assumir o papel discursivo de cidadão, para reclamar de um problema da sua comunidade (objetivo da interação), por meio da carta de reclamação (instrumento da interação). A carta foi entregue a seu destinatário real ${ }^{8}$ no final do projeto da SD (secretário municipal, prefeito, diretora da escola, etc.), por meio dos correios. A partir do cenário do agir linguageiro proposto para o projeto didático de produção da carta de reclamação, a SD assumiu o objetivo de desenvolver capacidades de linguagem para operacionalizar a escrita do gênero.

\title{
PRIMEIRA ETAPA DA SD DA CARTA DE RECLAMAÇÃO: CRIAÇÃO DE ESPAÇO PARA A NECESSIDADE E A MOTIVAÇÃO PARA O AGIR LINGUAGEIRO
}

Uma das características da metodologia das SD é a primeira fase desse procedimento didático: a apresentação da situação. Nessa etapa, o professor deve introduzir um problema de comunicação aos alunos, o qual deve ser "resolvido" com a produção de um gênero.

\begin{abstract}
A primeira dimensão é a do projeto coletivo de produção de um gênero oral ou escrito, proposto aos alunos de maneira bastante explícita para que eles compreendam o melhor possível a situação de comunicação na qual devem agir; qual é, finalmente, o problema de comunicação que devem resolver, produzindo um texto oral ou escrito (DOLZ; NOVERRAZ; SCHNEUWLY, 2004, p. 99 - grifos dos autores).
\end{abstract}

Essa etapa é responsável por, além de fazer com que os alunos compreendam a necessidade da produção do gênero, também sejam motivados para o desencadeamento da ação linguageira - uma motivação que promova um sincretismo entre a motivação compreensivel e a motivação eficaz. Isso porque, nessa proposta didática, a atividade de escrita não deve ser motivada simplesmente por uma necessidade formal de aprendizado - objetivos puramente didáticos. O professor precisa criar uma necessidade que parta do significado social do gênero. Ele precisa agir didaticamente de forma que o sentido (motivação eficaz) da ação de produzir o texto seja, para o aluno, equivalente ao significado social (motivação compreensível) do gênero, não ocorrendo, assim, uma alienação motivacional. Percebemos, pois, que o ISD visualiza a produção não como uma mera "tarefa escolar", mas como uma possibilidade de o aluno assumir-se como um agente-produtor "real", mesmo que em uma situação didatizada, muitas vezes, "simulada" discursivamente.

Como motivação para a escrita da carta de reclamação, a SD propôs a "atividade do púlpito", que consiste em usar um recurso didático existente em sala de aula, a $T V$

\footnotetext{
${ }^{8}$ As cartas foram enviadas, via correios, a seus destinatários, no final da SD, depois de os alunos as terem digitado e preenchido os envelopes. Algumas cartas obtiveram respostas, outras não.
} 
pendrive 9 , para exibir episódios do quadro "Púlpito" do programa televisivo Altas Horas, que tem como objetivo mostrar diferentes protestos da plateia, de forma aberta. Posteriormente, a SD propôs reproduzir o quadro "Púlpito" com os alunos, para que eles também pudessem fazer os seus protestos.

A princípio, a intenção foi colocar em evidência a "ação de reclamar", de uma maneira lúdica e sem muito vínculo com a rotina de sala de aula, para, em seguida, levar os alunos a refletirem sobre as diversas formas discursivas da reclamação. A necessidade da escrita da carta de reclamação surgiria, nesse sentido, naturalmente, das reflexões dos alunos. O papel do professor, como mediador dessa atividade, seria o de levar os alunos a perceber a importância de se saber reclamar com os instrumentos corretos, a fim de se conseguir um encaminhamento viável para a solução de um problema, assim como fazer com que eles tomassem consciência da significação social da escrita de uma carta de reclamação: alguém que assume o papel discursivo de cidadão para reclamar e solicitar uma solução para um problema social (no nosso caso, um problema da comunidade dos alunos). Ele também teria a tarefa de "provocar" conflitos nos alunos em relação à situação social da comunidade, pois seria desse meio social que emergiriam os problemas-alvo das cartas de reclamação - ou seja, as representações do referente textual.

Por essas razões, o tipo de atividade planificada para o módulo foi classificado por nós como "motivacional" e, o tipo de tarefa, como "participação oral". As atividades motivacionais para a escrita geralmente são trabalhadas de forma lúdica, sem uma sistematização muito rigorosa, uma vez que o objetivo é conseguir a adesão do aluno em relação a um projeto de escrita de um texto "real", mesmo que em um ambiente de ensino-aprendizagem. A atividade do Púlpito, por essa razão, mobilizou, fundamentalmente, tarefas na modalidade oral. Os alunos foram, pois, levados a perceber a importância do ato de reclamar e a tomar consciência das diferentes possibilidades discursivas para se concretizar esse ato, com ênfase, sobretudo, na carta de reclamação.

Ao reproduzirmos o quadro "Púlpito" com os alunos, tentamos demonstrar que a reclamação é uma ação discursiva que pode se concretizar por meio de várias formas textuais, e que cada uma delas emerge de um contexto diferente: para cada objetivo, tipo de reclamação, temos um gênero de texto diferente, com pessoas que assumem papéis discursivos diferentes (isso foi sistematizado na lousa, a partir das reclamações feitas pelos alunos na atividade do Púlpito). Dos exemplos apresentados pelos alunos é que emergiu o gênero "carta de reclamação". E foi desse ponto que começamos a levantar a necessidade de assumirmos o nosso papel de cidadão para reclamarmos dos problemas da comunidade (conteúdo temático das cartas). Foi somente após eles terem se motivado para a atividade de reclamar dos problemas locais que apresentamos o projeto de escrita da carta de reclamação. Nós não chegamos à sala de aula e colocamos como tarefa a escrita da carta. A produção escrita foi proposta como uma atividade discursiva autêntica, pois eles reclamariam de problemas reais da comunidade, por meio de um

\footnotetext{
${ }^{9}$ A TV pendrive faz parte do Projeto Multimídia, o qual destinou a todas as salas de aula da rede estadual do Paraná televisores com entradas para VHS, DVD, cartão de memória e pendrive e saídas para caixas de som e projetor multimídia.
} 
instrumento semiótico não criado nos muros da escola, mas que existe e circula na sociedade: a carta de reclamação. A carta não seria alvo apenas de um trabalho didático, mas teria enunciadores e destinatários legítimos; seus propósitos comunicativos ultrapassariam a mera atividade escolar.

Essa primeira etapa da SD possibilitou simularmos um esquema real da atividade de escrita da carta de reclamação, assim como esquematizada na Figura 1. Instigamos os alunos a perceberem a necessidade de reclamarem dos problemas da comunidade (por exemplo, ruas esburacadas), problemas esses que, por si sós, não desencadeariam uma ação linguageira. Para tanto, essa necessidade precisou se transformar em motivação, ou seja, eles precisaram ser motivados a buscar solução para o problema (motivo compreensível, que pode também ser tomado como motivo eficaz, dependendo da forma como o aluno representa a atividade). A professora necessitou instigar os alunos, então, a assumirem o papel discursivo de cidadão (não mais de aluno), com a intenção de reclamarem e solicitarem uma resolução para um problema local, por meio de um instrumento semiótico específico, a carta de reclamação. Para isso, eles deveriam ser dotados de capacidades de linguagem específicas que lhe possibilitassem agir nessa interação linguageira de forma eficaz. É nesse ponto que o professor precisou "vender o seu peixe", isto é, mostrar como seria importante o trabalho desenvolvido por meio da SD, pois ele seria todo voltado para "solucionar" os problemas operacionais de escrita da carta de reclamação que os alunos iriam escrever.

A atividade em questão proporcionou uma tomada de consciência em relação à ação de reclamar e um esclarecimento no que diz respeito aos contextos discursivos desse ato. Os alunos perceberam que cada reclamação tem um destinatário específico e uma (ou mais) forma discursiva para se concretizar. Outro ponto que indica a importância desse módulo são as reações perplexas dos alunos quando a professora diz que as cartas seriam endereçadas e enviadas aos seus destinatários reais. Comentários como "Professora, você tem certeza que o prefeito vai receber a minha carta?" eclodiram na sala (no caso da reclamação das ruas esburacadas), mostrando que os alunos já começavam a perceber a diferença entre as "redações" que normalmente faziam em sala de aula e a "produção" da carta de reclamação, cujo destinatário era uma pessoa do mundo extraescolar. Ou seja, eles perceberam que a atividade de escrita em que estavam sendo inseridos não era a mesma a que, comumente, eram convidados a participar como "redatores de textos escolarizados" ". Nesse novo cenário, eles tinham para quem escrever, por que escrever, sabiam que deveriam escrever não só como alunos, mas como alunos-sujeitos de seu dizer. É justamente a concepção de "produção de textos" defendida por Geraldi (2003) - textos escritos NA escola e não PARA a

\footnotetext{
${ }^{10}$ No período de pré-intervenção didática, presenciamos e recolhemos, na turma pesquisada, inúmeras atividades de mera redação escolar, como, por exemplo, as que solicitavam que o aluno escrevesse um texto que contemplasse uma lista de palavras pré-selecionadas pela professora. Interessante como após mais de 30 anos da primeira publicação da coletânea O Texto na Sala de Aula, organizada por Wanderley Geraldi (1984/2002), que introduz discussões sobre a importância do texto como objeto discursivo no processo de ensino da língua (discussões essas consolidadas e ampliadas pelo autor em Portos de Passagem, em 1991 - GERALDI, 2003), encontramos ainda evidências de contextos de escrita artificiais como os observados na turma pesquisada.
} 
escola. Os papéis discursivos já começavam a se distinguir nas representações dos alunos, mesmo que inconscientemente.

Entendemos que se esse primeiro momento da SD for bem elaborado e se o professor souber retomar em todos os módulos os elementos contextuais vislumbrados inicialmente (trazer para o plano da consciência), não é preciso, necessariamente, criar um módulo específico para trabalhar o "contexto de produção" de forma sistemática. Tudo vai depender, evidentemente, das características do gênero, da situação e dos objetivos da intervenção. No nosso caso, optamos por explorar alguns dos elementos contextuais, que entendemos ser importantes para a escrita do gênero, em numa atividade com o foco no confronto contextual e discursivo entre alguns gêneros epistolares. Dessa forma, o aluno pôde perceber que a carta de reclamação possui tanto semelhanças como diferenças em relação a outras modalidades de carta - carta pessoal, do leitor, comercial, etc. -, não somente no plano estrutural, mas também no situacional e discursivo, ao mesmo tempo em que internalizava o contexto de produção da carta de reclamação, objeto de ensino da $\mathrm{SD}$.

\section{EXEMPLO DA SINCRONIA ENTRE SIGNIFICAÇÃO SOCIAL E SENTIDO ATRIBUÍDO AO AGIR LINGUAGEIRO NO CONTEXTO DIDÁTICO DO ENSINO DA LÍNGUA}

$\mathrm{Na}$ atividade da Púlpito tivemos reclamações sobre: 1) a função do presidente de sala; 2) a quantidade de tarefas de casa; 3 ) a professora de matemática; 4) quantidade de aulas; 5) o cancelamento do CELEM ${ }^{11}$ (Centro de Línguas Estrangeiras Modernas) de espanhol; 6) ruas esburacadas; 7) mato em frente à escola; 8) material didático sem uso; 9) pessoas que passam fome; 10) horário de início das aulas. Interessante, nessa lista, é que três problemas apontados na atividade apareceram, depois, nas produções finais dos alunos (5, 6 e 7), o que demostra o reflexo da atividade motivacional no agir linguageiro dos alunos, já que a atividade didática não direcionou as reclamações: elas partiram das necessidades individuais dos alunos.

Para ilustrar a discussão trazemos uma breve análise do desenvolvimento das capacidades de linguagem de um dos alunos ${ }^{12}$ que reclamaram do cancelamento do CELEM de Espanhol, tanto na primeira como na última produção ${ }^{13}$, revelando que a motivação para a escrita da sua carta partiu, primeiramente, de uma necessidade social, uma vez que ficou evidente o seu descontentamento com a situação protestada. Para esse aluno, com certeza, a motivação para a atividade da escrita da carta foi, ao mesmo tempo, compreensível (significação social da atividade) e eficaz (sentido pessoal da atividade).

\footnotetext{
11 O Centro de Línguas Estrangeiras Modernas é uma oferta extracurricular e gratuita de ensino de Línguas Estrangeiras nas escolas da Rede Pública do Estado do Paraná, destinado a alunos, professores, funcionários e à comunidade.

12 Tivemos dois alunos que reclamaram desse problema. Para o aluno cuja produção foi selecionada para análise demos o nome fictício de Gabriela Barros. O nome da professora - Maria - também foi criado para efeitos de pesquisa.

${ }^{13}$ Esse aluno já reclamou desse problema na atividade do Púlpito feita em sala de aula.
} 
A seguir, quadro com a produção inicial - feita logo após a atividade de motivação (Púlpito) -, e a produção final, já com os ajustes feitos no processo de revisão e reescrita da carta de reclamação.

\section{Quadro 3 - Primeira e última produção de uma carta de reclamação}

\begin{tabular}{|c|c|}
\hline $\begin{array}{l}\text { NDR(a): primeira produção } \\
\text { (simulação do layout da escrita manual) }\end{array}$ & NDR(b): produção final digitada \\
\hline $\begin{array}{l}\text { Londrina, } 28 \text { de agosto de } 2009 \text {. } \\
\text { Prezada Diretora } \\
\text { Olá Diretora Bruna. } \\
\text { Fiquei muito contente com o projeto do celem } \\
\text { que colocaram na escola, bastantes alunos se escreveram, } \\
\text { mas nem todos iam nas aulas. Só que não achei muito } \\
\text { certo as atitudes dos professores, eles fizeram um abaixo } \\
\text { assinado para tirar o espanhol, e sem comunicar a } \\
\text { professora Maria que nos ensina espanhol. Eu sei que o } \\
\text { minimo de alunos é vinte, mas minha turma tem onze } \\
\text { indo frequênte nas aulas e uns três que não são } \\
\text { matriculados, e sei que esses onze estão se esforsando } \\
\text { para ir, acho que não é certo tirar o espanhol por causa da } \\
\text { queles que não estão indo, e o esforço daqueles que estão } \\
\text { indo? } \\
\text { Agradeço sua atenção, Aguardo resposta } \\
\text { Aluna: Gabriela Barros } 5^{\text {a MA }} \\
\text { Professora: Maria Cordeiro }\end{array}$ & $\begin{array}{l}\text { Londrina, } 27 \text { de novembro de } 2009 \\
\text { Ref.: Cancelamento do Celem } \\
\text { Prezado Diretor do N.R.E. de Londrina, } \\
\text { Sou aluna da escola estadual Olavo Bilac. No } \\
\text { ano de } 2009 \text { me matriculei no Celem de espanhol, porém } \\
\text { passou um tempo e fiquei sabendo que ele seria } \\
\text { cancelado devido à falta de frequência dos alunos, } \\
\text { mesmo sendo o ano da sua implantação. } \\
\text { Penso que não deveria ser cancelado o curso, } \\
\text { pois as pessoas que fazem o Celem, com certeza, teriam } \\
\text { oportunidades de um futuro melhor e, sem dúvida, o } \\
\text { Celem de espanhol proporciona um aprendizado muito } \\
\text { bom para os alunos. Em primeiro lugar, não são em } \\
\text { todas as escolas que existe essa oportunidade. Em } \\
\text { segundo lugar, o espanhol é a segunda língua mais usada } \\
\text { no comércio. Finalmente, a quarta mais falada no } \\
\text { mundo. } \\
\text { Dessa forma, queria pedir para que tomassem as } \\
\text { devidas providências. } \\
\text { Muito obrigada pela atenção, } \\
\text { Gabriela Barros } \\
\text { Aluna da escola Olavo Bilac - } 5^{\text {a MA }} \\
\text { Projeto Cidadania: profa . Maria Cordeiro }\end{array}$ \\
\hline
\end{tabular}

Em relação à primeira versão, foi o texto que mais se aproximou da modelização do gênero feita para a pesquisa. Nele, é possível depreender as várias "etapas" que compõem o plano global da carta de reclamação. Há um cabeçalho com local e data, uma saudação inicial, a descrição do problema, junto com a ideia defendida, argumentos para justificar esse posicionamento, uma saudação final e a identificação do destinatário. Embora explicitamente não seja textualizada uma solicitação para a resolução do problema, ela pode ser recuperada implicitamente pelos posicionamentos assumidos no texto e pela pergunta retórica deixada no final da carta. Nessa produção não há um tom agressivo (como se verificou em várias cartas de alunos), embora a carta seja bastante crítica. Verificamos que quando o aluno consegue desenvolver uma discursividade argumentativa, o caráter reivindicatório do texto fica "camuflado", sobressaindo, dessa forma, o problema-alvo da reclamação. Isso faz com que a ação linguageira de reclamar de um problema tenha mais chances de atingir seus objetivos reais. No caso da carta em questão, como o destinatário era a diretora da escola, percebemos que o aluno faz uma representação contextual menos formalizada, pois, apesar de a diretora ser uma autoridade, está próxima dos alunos, é acessível no 
cotidiano deles. É por essa razão que a saudação é feita com um "Olá" - talvez a mesma que o aluno use no seu dia a dia escolar para cumprimentar a diretora.

$\mathrm{Na}$ versão final, esse aluno consegue um bom desenvolvimento quanto à capacidade de ação. Seu texto avança bastante em relação à formalidade requerida por esse tipo de interação, evidenciando que houve uma reconcepção (cf. MACHADO; LOUSADA, 2010) no que diz respeito à representação contextual da interação enunciador/destinatário. Os propósitos didáticos da atividade da escrita ficam, assim, "camuflados", sobressaindo-se a ação linguageira de um cidadão-aluno reclamando do cancelamento do CELEM de Espanhol da sua escola e pedindo providências para que seja resolvido o problema.

No que diz respeito à capacidade discursiva, mesmo a primeira versão apresentada já sendo satisfatória, o aluno consegue melhorar a sua linha argumentativa. A versão final está mais objetiva e com mais força argumentativa, uma vez que traz informações coletadas nas pesquisas solicitadas durante a SD como sustentação para a tese defendida: "o espanhol é a segunda língua mais usada no comércio e a quarta mais falada no mundo". Faltou, nesse caso, uma voz de autoridade para sustentar os dados. Como não trabalhamos as formas de sustentação dos argumentos - exemplificação, definições, voz de autoridade, etc. - não fizemos nenhuma intervenção nesse aspecto, pois acreditamos que uma única SD não consegue dar conta de todas as dimensões ensináveis do gênero. Na nova versão do texto, o aluno explicita o referente textual, apresentado como uma opção para a escrita da carta de reclamação, e também a solicitação da solução do problema. Interessante que ele não relata o problema minuciosamente como na primeira versão: o relato é bem sintético. Ele dá prioridade à apresentação de argumentos em defesa da sua opinião. Há, pois, uma mudança na representação do gênero: não seria um texto para apresentar um problema, mas para "lutar" pela sua resolução. Já o tom do texto atinge um grau de formalidade bem maior do que na primeira versão e mais adequado ao gênero.

$\mathrm{Na}$ versão final, o aluno também avança bastante em relação à capacidade linguístico-discursiva, a mais problemática na primeira carta. Os problemas ortográficos/gramaticais são sanados e a estética do texto se enquadra nos padrões textuais formais: paragrafação coerente, pontuação adequada, adentramento dos parágrafos. Em relação aos mecanismos de textualização, a conexão textual é a que teve maior avanço. Isso se deve, é claro, ao ensino sistematizado desse aspecto linguísticodiscursivo em um módulo da SD. Diferentemente da primeira versão, na qual o aluno utilizava apenas o "mas" e o "e", na versão final o aluno mobiliza os seguintes organizadores textuais: "porém”, "pois”, “com certeza”, "sem dúvida”, “em primeiro lugar", "em segundo lugar", "finalmente", "dessa forma”. Todos eles foram trabalhados em dispositivos didáticos elaborados especialmente para a SD, mostrando como o aluno necessita de "modelos" para poder imitar durante a fase de internalização de um gênero textual. Essa imitação, com o tempo, deixa de ser necessária, e o aluno passa a se autorregular no momento da produção textual, seja do gênero estudado ou de outro que mobilize a mesma estratégia linguístico-discursiva. 
Neste texto, tendo como ilustração o processo de escrita de uma carta de reclamação em ambiente escolar de ensino da Língua Portuguesa, apresentamos um panorama teórico do agir - geral e discursivo -, a fim de se chegar a um quadro conceitual da ação linguageira usado por nossa pesquisa como parâmetro para a análise do ato verbal em situação de ensino-aprendizagem da língua. Esse quadro teórico é resultado de empréstimos dos conceitos da Teoria da Atividade de Leontiev (1983, 2006) e da sua adaptação, feita por pesquisadores do ISD (BRONCKART, 2006, 2008). Para complementar essa discussão, apresentamos, também, a visão do ISD em relação ao contexto da produção linguageira, pelo fato de esse ser indissociável da própria ação de linguagem.

Nesse sentido, procuramos explicitar como o ato da produção textual pode ser vivenciado em sala de aula, levando-se em consideração a necessidade e a motivação pilares da ação linguageira -, a partir da elaboração de um módulo (ou oficina) "motivacional", na etapa da SD denominada "apresentação da situação". Acreditamos que essa fase da SD é de suma importância para seu "sucesso", uma vez que é a partir dela que se "criam" necessidades e motivos para a escrita de gêneros de textos que circulam socialmente, representativos da cultura letrada (de prestígio ou não), e não meros textos escolarizados (ou "redações") desprovidos de contextos situacionais. Essa metodologia de apropriação da língua toma sempre como referência práticas sociais materializadas em textos/discursos e, para tanto, o aluno precisa, segundo Leontiev (2006), de uma tomada de consciência da esfera social envolvida nessa prática. Tomada essa que passa desde a percepção da necessidade de escrita do gênero até $\mathrm{o}$ desenvolvimento de capacidades de linguagem para operacionalizá-lo - conceitos esquematizados no quadro da ação linguageira sistematizado para a pesquisa (Quadro $1)$.

Trouxemos, também, a produção de uma carta de reclamação por um aluno envolvido no projeto didático (objeto de análise da nossa pesquisa de doutoramento) como exemplo de uma ação linguageira na qual a motivação compreensível da escrita transforma-se em motivação eficaz, mostrando que a necessidade da resolução do problema (referente da carta) foi o que realmente motivou a ação da escrita do aluno. Esse exemplo demonstra como o aluno precisa começar a tomar voz no processo de aprendizagem, se tornando ator da sua escrita - algo que só se consegue quando damos oportunidade de ele vivenciar uma ação linguageira desprovida da artificialidade construída tradicionalmente pela escola para ensinar a língua materna.

É importante pontuar que essa imbricação entre as motivações - compreensível e eficaz - também ocorreu no processo de escrita dos outros alunos da turma, pois a SD foi toda direcionada para esse fim: fazer com que os propósitos comunicativos do gênero como objeto social se sobressaíssem em relação aos do gênero como objeto de ensino. Evidentemente, o ensino caminha para uma direção e a aprendizagem nem sempre o acompanha. A forma como ess imbricação se deu foi diversificada, pois cada aluno é um contexto em particular. Por exemplo, houve casos em que, mesmo a escrita evidenciando que o aluno estava incomodado com o problema relatado na carta, ele não 
se mostrava motivado a trazer argumentos reais, coletados da sua experiência, para defender seu ponto de vista. Mesmo com todas as desigualdades próprias do processo de aprendizagem, a intervenção didática conseguiu atingir os seus propósitos, uma vez que fez com que os alunos vivenciassem uma experiência linguageira relevante como agentes-produtores de um gênero da esfera da cidadania.

Nesse sentido, acreditamos que é de suma importância, na formação docente do professor letrador - tanto a inicial como a continuada -, a discussão de todos esses conceitos envolvendo o agir linguageiro, uma vez que ela pode clarear muitos aspectos envolvidos no processo do ensino da produção de textos em ambiente escolar.

\section{REFERÊNCIAS}

BAKHTIN, M. Gêneros do discurso. In: São Paulo: Martins Fontes, 2003. p. 261-306. Estética da criação verbal. Trad. Paulo Bezerra. 4. ed.

BARROS, E. M. D. de. Aproximações entre o funcionamento da Metodologia das Sequências Didáticas e o conceito de Zona de Desenvolvimento Proximal. Calidoscópio, São Leopoldo, v. 11, n. 1, p. 76-89, jan./abr. 2013.

BORTONI-RICARDO, S. M. O professor pesquisador: introdução à pesquisa qualitativa. São Paulo: Parábola, 2008.

BRONCKART, J-P. Atividade de linguagem, textos e discursos: por um interacionismo sócio-discursivo. Trad. Anna Rachel Machado e Péricles Cunha. 2. reimpr. São Paulo: EDUC, 2003.

Atividade de linguagem, discurso e desenvolvimento humano. Org. Anna Rachel Machado e Maria de Lourdes Meireles Matencio. Trad. Anna Rachel Machado et al. Campinas/SP: Mercado de Letras, 2006.

O agir nos discursos: das concepções teóricas às concepções dos trabalhadores. Trad. Anna Rachel Machado. Campinas: Mercado de Letras, 2008.

DOLZ, J.; NOVERRRAZ, M.; SCHNEUWLY, B. Seqüências didáticas para o oral e a escrita: apresentação de um procedimento. In: SCHNEUWLY. B.; DOLZ, J. (org.). Gêneros orais e escritos na escola. Trad. de Roxane Rojo e Glaís Sales Cordeiro. Campinas: Mercado de Letras, 2004, p. 95-128.

DOLZ, J.; SCHNEUWLY, B. Gêneros e progressão em expressão oral e escrita - elementos para reflexões sobre uma experiência suíça (francófona). In: SCHNEUWLY, B.; DOLZ, J. (Orgs.). Gêneros orais e escritos na escola. Campinas: Mercado de Letras, 2004. p. 41-70.

GERALDI, J. W. (Org.). O texto na sala de aula. São Paulo: Ática, 1984/2002.

Portos de passagem. 4. tir. São Paulo: Martins Fontes, 2003.

HABERMAS, J. Consciência moral e agir comunicativo. Trad. De Guido A. de Almeida. Rio De Janeiro: Tempo Brasileiro, 1989.

Teoría de la acción comunicativa, I: racionalidad de La acción y racionalización social. Madrid: Taurus Humanidades, 1999.

KLEIMAN, A. B. Modelos de letramento e as práticas de alfabetização na escola. In: (Org.). Os significados do letramento: uma nova perspectiva sobre a prática social da escrita. 9. reimpr. Campinas: Mercado de Letras, 2006, p. 15-61.

LEONTIEV, A. N. Actividad, conciencia y personalidad. Havana: Editorial Pueblo Y Educación, 1983.

Uma contribuição à teoria do desenvolvimento da psique infantil. In: VIGOTSKI, L.S.; LURIA, A.R.; LEONTIEV, A.N. Linguagem, desenvolvimento e aprendizagem. 10. ed. São Paulo: Cone, 2006, p.59-83.

MACHADO, A. R. (Org.). A perspectiva interacionista sociodiscursiva de Bronckart. In: MEURER, J. L.; BONINI, A. MOTA-ROTH, D. (Orgs.). Gêneros: teorias, métodos, debates. São Paulo: Parábola, 2005, p.237-259. 
MACHADO, A. R.; LOUSADA, E. A apropriação de gêneros textuais pelo professor: em direção ao desenvolvimento pessoal e à evolução do "métier". Linguagem em (Dis)curso, Palhoça, v. 10, n. 3, p. 619-633, set./dez. 2010.

MACHADO, A. R. et al. Relações entre linguagem e trabalho educacional: novas perspectivas e métodos no quadro do interacionismo sociodiscursivo. In: CRISTOVÃO, V. L.; ABREU-TARDELLI, L. S.

(Orgs.) Linguagem e educação: o trabalho do professor em uma nova perspectiva. Campinas: Mercado de Letras, 2009.

NASCIMENTO, E. L. A dupla semiotização dos objetos de ensino-aprendizagem: dos gestos didáticos fundadores aos gestos didáticos específicos. Signum, Londrina, v. 14, n.1, p. 421-445, jun. 2011.

SCHNEUWLY, B.; DOLZ, J. (Orgs.). Gêneros orais e escritos na escola. Campinas: Mercado de Letras, 2004.

SIEBENEICHLER, F. B. Jürgen Habermas: razão comunicativa e emancipação. Rio de Janeiro: Tempo Brasileiro, 1989.

VIGOTSKI, L. S. Pensamento e linguagem. Trad. Jefferson L. Camargo. 4. ed. São Paulo: Martins Fontes, 2008.

Recebido em: 03/07/14. Aprovado em: 06/03/15.

Title: The discursive action and the textual production at school

Author: Eliana Merlin Deganutti de Barros

Abstract: In this article, maintaining as object the analysis of writing a complaint letter process anchored at the didactic sequences methodology, we present a theoretical framework of the communicative action in order to achieve a conceptual frame regarding the discursive action used in our doctoral studies as parameter for the analysis of the textual production for the language teaching-learning purpose. This frame is result of the association of concepts from Activity Theory by Leontiev and their appropriation by researchers affiliated to the Socio-discursive Interactionism. The awareness regarding the process that evolves the discursive action raises as extremely important for clarification of the aspects involved in the teaching of text production process at school.

Keywords: Activity Theory. Discursive action. Textual production.

Título: La acción del discurso y la práctica de producción textual en la escuela

Autor: Eliana Merlin Deganutti de Barros

Resumen: En este artículo, teniendo como objeto de análisis el proceso de escrita de una carta de reclamación, basado en la metodología de las secuencias didácticas, presentamos un panorama teórico de la acción comunicativa para llegar a un cuadro conceptual de la acción del discurso usado por nuestra pesquisa de doctoramiento (abordaje cualitativointerpretativa, con carga etnográfico-intervencionista) como parámetro para el análisis de la producción textual en situación de enseñanza y aprendizaje de la lengua. Ese cuadro es resultado de préstamos de conceptos de la Teoría de la Actividad de Leontiev y da su apropiación por los investigadores del Interaccionismo Socio-discursivo. La concientización del proceso que involucra la acción del discurso se mostró de gran importancia en el aclaramiento de aspectos involucrados en el proceso de enseñanza de la producción de textos en ambiente escolar.

Palabras-clave: Teoría de la actividad. Acción del discurso. Producción de textos. 